\title{
WEIGHT LOSS OF FIVE COMMERCIALLY AVAILABLE DENTURE TEETH AFTER TOOTHBRUSHING WITH THREE DIFFERENT DENTIFRICES
}

\author{
PERDA DE MASSA DE CINCO MARCAS DE DENTES ARTIFICIAIS DISPONIVEIS NO \\ MERCADO APÓS ESCOVAÇÃO COM TRÊS DIFERENTES DENTIFRÍCIOS
}

Karina Matthes de FREITAS ${ }^{1}$, Helena de Freitas Oliveira PARANHOS ${ }^{2}$

1- DDS, MSc, PhD, Graduate student, Department of Dental Materials and Prosthesis, Ribeirão Preto Dental School, University of São Paulo. 2- DDS, MSc, PhD, Associate professor, Department of Dental Materials and Prosthesis, Ribeirão Preto Dental School, University of São Paulo.

Corresponding address: Karina Matthes de Freitas - Rua Alfredo Braghetto, 140 - Cep.: 14090-149 - Ribeirão Preto - SP

Fone/Fax: +55-16-3624 7714 - e-mail: kamatthes@yahoo.com.br

Received: July 01, 2005 - Modification: October 07, 2005 - Accepted: August 08, 2006

\begin{abstract}
$B$ rushing is the most common cleansing method employed on complete dentures and it may damage the integrity of acrylic resin, the main component of this type of prosthesis. This study evaluated the abrasion resistance of artificial teeth with different number of acrylic layers, and the abrasiveness of specific and non-specific dentifrices for denture cleaning. The abrasion test was conducted by a tooth brushing device, using soft toothbrushes under load (200g). Sixty artificial teeth specimens were manufactured, 12 from each brand: Vipi-Dent Plus (Dental Vipi), Trubyte Biotone (Dentsply), Trilux (Ruthinium), Ivostar (Ivoclar) and SR Vivodent PE (Ivoclar). Three brands of dentifrices were selected: Colgate (Colgate-Palmolive), Bonyplus (Bonyf AG) and Dentu-Creme (Dentco). Distilled water was used as control. The brushing time was 100 minutes, at 356 strokes/ minute. The specimens were weighed on an analytical balance before and after the abrasion test. Analysis of dentifrices' abrasive particles was made by scanning electron microscopy (SEM). Two-way ANOVA and Tukey tests were employed $(\alpha=0.05)$. The general mean of weight loss values were obtained: $6.1 \mathrm{mg}$ (Ivostar); $6.0 \mathrm{mg}$ (Trilux); $5.9 \mathrm{mg}$ (Trubyte); $5.8 \mathrm{mg}$ (Vipi); $5.3 \mathrm{mg}$ (Vivodent). The abrasiveness difference among teeth brands was not statistically significant. The Colgate dentifrice produced the greatest weight reduction (10.1 mg), followed by Dentu-Creme (7.6 mg). Bonyplus was the least abrasive (2.4 mg), similar to the distilled water used as control group $(3.1 \mathrm{mg})(\mathrm{p}=0.05)$. It was concluded that all acrylic teeth presented similar abrasion resistance. Specific dentifrices for dentures tend to cause less damage to acrylic resin.

Uniterms: Acrylic resins; Tooth, artificial; Dentifrice; Tooth, abrasion.
\end{abstract}

\section{RESUMO}

A

escovação é o método mais empregado para higienização de próteses totais e pode causar danos à resina acrílica, seu principal componente. Este estudo avaliou a resistência à abrasão de dentes de resina acrílica, com diferentes camadas de prensagem, frente a dentifrícios específicos e não específicos para higienização de dentaduras. O ensaio de abrasão foi realizado utilizando-se uma máquina de escovação, com escovas macias sob carga de $200 \mathrm{~g}$. Foram confeccionados 60 corposde-prova, 12 de cada marca comercial: Vipi-Dent Plus (Dental Vipi), Trubyte Biotone (Dentsply), Trilux (Ruthinium), Ivostar (Ivoclar), SR Vivodent PE (Ivoclar). Foram empregados os dentifrícios: Colgate (Colgate Palmolive), Bonyplus (Bonyf AG) e Dentu-Creme (Dentco). Água destilada foi utilizada como controle. O tempo de escovação foi 100 minutos, a 356 rotações/ minuto. Os corpos-de-prova foram pesados em balança analítica antes e após os ensaios. As partículas abrasivas dos dentifrícios foram analisadas em microscopia eletrônica de varredura (MEV). Os testes ANOVA e Tukey $(\alpha=0,05)$ foram empregados. A perda de peso média dos dentes foi: 6,1 mg (Ivostar); 6,0 mg (Trilux); 5,9 mg (Trubyte); 5,8 mg (Vipi); 5,3 mg (Vivodent). Não houve diferença significante entre as marcas de dentes. O dentifrício Colgate causou maior perda de massa (10,1 mg), seguido pelo Dentu-Creme (7,6 mg). O Bonyplus foi o menos abrasivo (3,1 mg), sem diferença estatística em relação ao controle (2,4 mg) $(\mathrm{p}=0,05)$. Foi concluído que todos os dentes foram igualmente resistentes à abrasão, independentemente do número de prensagens. Dentifrícios específicos para próteses totais geraram menos danos à superfície acrílica.

Unitermos: Resinas acrílicas; Dente artificial; Dentifrício; Abrasão dentária. 


\section{INTRODUCTION}

Acrylic resin is the most used material in prosthodontics. While its hardness turns denture adjustment easier, its integrity may be damaged by brushing, mastication and immersion in chemical products ${ }^{19,20}$. The association of toothbrush and dentifrice is the most common method for denture hygiene ${ }^{3},{ }^{15,18}$ because it is cheap and effective on denture cleansing ${ }^{16}$. However, the acrylic resin may be damaged because of its low abrasion resistance ${ }^{5}$. This abrasion caused by brushing may result in mass loss, surface roughness, loss of surface polishing and, consequently, the maintenance of denture hygiene becomes more difficult ${ }^{13}$.

Dentifrices have generally a complex composition, varying among different brands. The principal components are: water, detergent, thickening agent, specific coloring, flavoring and abrasive agents ${ }^{5,6,8}$. The most commonly used abrasives in dentifrices are silica and calcium carbonate ${ }^{14}$. Abrasion studies "in vivo" have not been widely reported due to difficulties on method standardization. Most "in vitro" studies employ motor-driven brushing machines, in order to standardize time, speed, frequency of brushes' strokes, applied load and the amount of dentifrice ${ }^{11,20}$. Some studies have associated saliva in order to simulate oral conditions ${ }^{9}$. The methods used on measurement of abrasion are: weight loss ${ }^{18}$, surface roughness ${ }^{7}$, microscopic examination $^{4,17}$, radiometric technique ${ }^{1}$, photographic analysis $^{17}$, checking of brightness loss ${ }^{12,18}$, measuring of thickness reduction of complete crown acrylic veneer face and of denture bases ${ }^{4,16}$.

Just a few specific references on abrasion resistance of artificial teeth by brushing were found ${ }^{9,17}$. This type of investigation is clinically interesting, aimed at the appropriate selection of materials and methods for denture hygiene, with no significant damage to denture.

The aim of the present investigation was to evaluate the weight loss of five commercially available denture teeth after toothbrushing with three different dentifrices. The hypothesis that different denture teeth and dentifrices produce different weight loss after toothbrushing was tested in this study.

\section{MATERIALAND METHODS}

Table 1 presents the commercial brands of the artificial teeth used in this study. These products were selected as being representative of those available on the market.

Sixty specimens were made from 60 maxillary central incisors, 12 from each brand. Their form and size were matched as closely as possible, so that they could be cut on dimensions: $6 \mathrm{~mm}$ length, $6 \mathrm{~mm}$ wide, $2.5 \mathrm{~mm}$ thick. The buccal face of the teeth was kept. All of them were stored in water at $37^{\circ} \mathrm{C}$ for 7 days before the test ${ }^{22}$, separated by brand, in different flasks.

The specimens were removed from the water bath and rinsed with tap water. Afterwards, they were cleaned for one minute in an ultrasonic bath with deionized water containing 1\% of detergent (Limpol neutral, Bombril S/A, São Bernardo do Campo, Brazil) and dried with absorbing paper. After 1 minute, they were weighed in analytical balance with an accuracy of $0.1 \mathrm{mg}$ (Metler Toledo GMbH, Laboratory \& Weighing Technologies, Greifensee, Switzerland) ${ }^{22}$.

For artificial brushing tests, the specimens were coupled in special plates in order to fit them to the brushing machine, with buccal faces exposed to abrasion. The machine used (Precision Shop, University of São Paulo, Ribeirão Preto, São Paulo, Brazil) was equipped with 6 brush holders and pans, so that 6 specimens were brushed simultaneously. The brush holders were composed by three screws that fixed the brushes and allowed them to be leveled and regulated to apply a load of $200 \mathrm{~g}^{18,19,22}$ on the teeth. Sixty soft toothbrushes with 26 nylon bristles $(0.25 \mathrm{~mm}$ diameter and $10.00 \mathrm{~mm}$ length per bundle) were used (Tek, Johnson\&Johnson, São José dos Campos, São Paulo, Brazil). The specimens and the slurry of dentifrice were placed in the pans. The frequency was 356 strokes/minute and the trail of the toothbrushes was $3.8 \mathrm{~cm}$.

Table 2 presents the employed dentifrices. Slurries with $30 \mathrm{ml}$ of water and $15 \mathrm{ml}$ of dentifrice (2:1) were prepared for each specimen ${ }^{22}$. Distilled water solely was used on the control group. Brushing time was 100 minutes, resulting in a total of 35,600 strokes for each test. The slurry remained unchanged during the test. All specimens were submitted to the same standardized brushing conditions.

After the test, the specimens were removed from the plates, subjected to the same cleaning and drying process and weighed in the same analytical balance. Weight of the

TABLE 1- Specifications of artificial teeth tested

\begin{tabular}{|c|c|c|c|}
\hline Commercial brand & Manufacturer & City-State & Country \\
\hline Trubyte Biotone & Dentsply Ind. Com. Ltda. & Petrópolis - RJ & Brazil \\
\hline Vipi-Dent Plus & $\begin{array}{l}\text { Dental Vipi Ltda. Ind. Com. Imp. e Exp. } \\
\text { de produtos odontológicos }\end{array}$ & Pirassununga - SP & Brazil \\
\hline Trilux & Ruthinium Group & Badia Polesine & Italy \\
\hline Ivostar & Ivoclar Vivadent AG & Schaan & Liechtenstein \\
\hline SR-Vivodent PE & Ivoclar Vivadent AG & Schaan & Liechtenstein \\
\hline
\end{tabular}


specimens was performed in the same room, at the same time each day. Atmospheric changes were not considered. The results were obtained by the difference between the initial and final weight (mg). Two-way ANOVA and Tukey tests were used for statistical analysis $(\alpha=0.05)$.

Scanning electronic microscope (JEOL JSM5410, Japan) was used to provide better details about the abrasive particles of the dentifrices.

\section{RESULTS}

The results exhibited normal and homogeneous distribution, so the two-way analysis of variance test (p critical: 0.05) was used for the statistical study. Table 3 shows the two-way ANOVA results.

The difference among the artificial teeth was not statistically significant and the interaction between the variation factors was not significant either. However, differences among the dentifrices were found.

The Tukey test showed that Colgate dentifrice produced the greatest weight loss, followed by Dentu-Creme, while Bonyplus was the least abrasive $(\mathrm{p}<0.05)$, with no difference of control group (Table 4).

The microscopic analysis showed that Colgate abrasive particles have irregular spherical form, irregular size and heterogeneous distribution, while Dentu-Creme's have regular form, small size and homogeneous distribution (Figs. 1 and 2). Bonyplus did not present any abrasive particle.

\section{DISCUSSION}

Since dentifrice and toothbrush association is one of the most common methods used for oral structures hygiene, it should promote good cleaning with minimal damage to teeth, gum, restorative and prosthetic materials. So, it is important to evaluate the abrasion resistance to brushing of acrylic teeth used for denture manufacturing. The acrylic resin hardness, type of abrasive agent and its concentration, dimension and form of abrasive particles, toothbrush used and load applied are some of the different factors that influence the abrasion of acrylic resin by brushing ${ }^{1,3,5}$. In this study, the variation factors were different types of dentifrices and commercial brands of denture teeth.

Colgate and Dentu-Creme dentifrices use calcium carbonate as abrasive particles. Their manufacturers do not

TABLE 4- Weight loss of the artificial teeth promoted by the dentifrices used in this study (mean \pm standard deviation)

\section{Dentifrice}

Colgate Dentu-Creme Bonyplus Control

\begin{tabular}{llll}
$10.1^{\mathrm{a}}$ & $7.6^{\mathrm{b}}$ & $2.4^{\mathrm{c}}$ & $3.1^{\mathrm{c}}$ \\
$(2.2)$ & $(2.2)$ & $(1.5)$ & $(0.9)$ \\
\hline
\end{tabular}

Means with the same letter are not significantly different.

TABLE 2- Characteristics of dentifrices employed

\begin{tabular}{llllll}
\hline Dentifrice & Manufacturer & City & Country & Abrasive particles & Indication \\
\hline $\begin{array}{l}\text { Colgate } \\
\text { com cálcio }\end{array}$ & $\begin{array}{l}\text { Colgate-Palmolive } \\
\text { Divisão da Kolynos } \\
\text { do Brasil }\end{array}$ & Osasco & Brazil & Calcium carbonate & Natural teeth \\
Bonyplus & BonyfAG & Vaduz & Liechtenstein & None & Complete \\
& Block Drug Company & Jersey City & U.S.A. & Calcium carbonate & Complete \\
Dentu-creme & Dentco Inc. & & & & dentures \\
\hline
\end{tabular}

TABLE 3- ANOVA table for weight loss of artificial teeth

\begin{tabular}{llllll}
\hline & \multicolumn{1}{c}{ df } & SS & V & F \\
\hline $\mathrm{D}$ & 614.3453 & 3 & 204.7818 & 52.12 & * \\
$\mathrm{T}$ & 5.4281 & 4 & 1.3570 & 0.35 & $\mathrm{~ns}$ \\
$\mathrm{D} \times \mathrm{T}$ & 20.0774 & 12 & 1.6731 & 0.43 & $\mathrm{~ns}$ \\
Residuals & 157.1623 & 40 & 3.9291 & & \\
Total variation & 797.0131 & 59 & & & \\
\hline
\end{tabular}

D: dentifrices; T: artificial teeth; $\quad$ *: $\mathrm{P}<0.05 ; \quad$ ns: no significance. 
give detailed information about these particles. So, MEV analysis of these abrasive particles was required. Results showed that Colgate was statistically more abrasive than Dentu-Creme. Microscopic analysis showed that Colgate's abrasive particles presented irregular spherical form, irregular size and heterogeneous distribution, while Dentu-Creme's abrasive particles presented regular form, small size and homogeneous distribution (Figs. 1 and 2). This confirms the results of Camargo, et al. ${ }^{1}$ (2001), which show the importance of the abrasive agent's particles form, size and distribution on the abrasiveness capability of the dentifrice. On the other hand, Haselden, et al. ${ }^{5}$ (1998) affirmed that the interaction of different resins with dentifrices containing markedly differing compositions could well lead to alterations to the surface of resins, influencing the abrasion. Their study showed that Colgate was more abrasive for self-cured acrylic resins, while Dentu-Creme was more abrasive for heat-cured acrylic resins.

Brushing with distilled water caused a minimum weight reduction, confirming the results from other studies ${ }^{19}$. Bonyplus has no abrasive particle and its results were statistically similar to the control group. Clinical studies are required for this dentifrice, in order to determine its cleaning power. Some studies indicate the importance of the dentifrice abrasiveness on promoting efficient cleaning, because brushing with water solely does not remove stains and

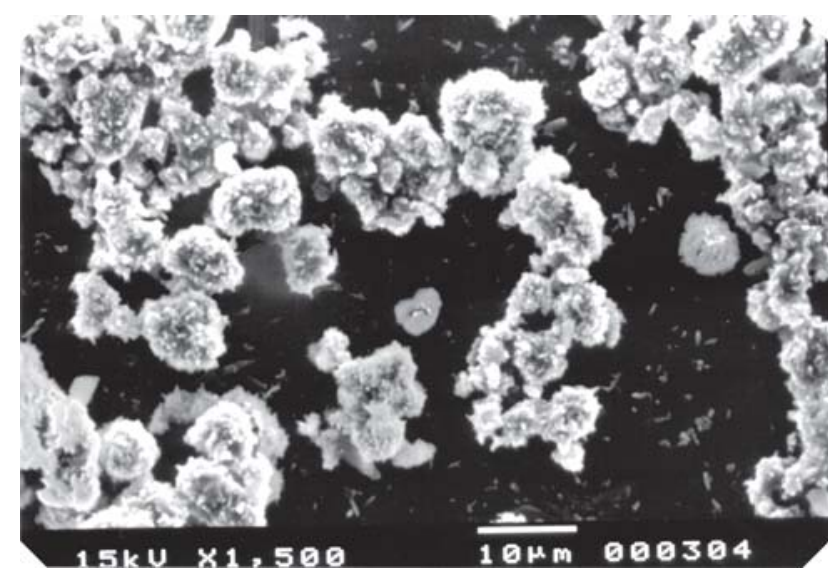

FIGURE 1- Abrasive particles of Colgate dentifrice

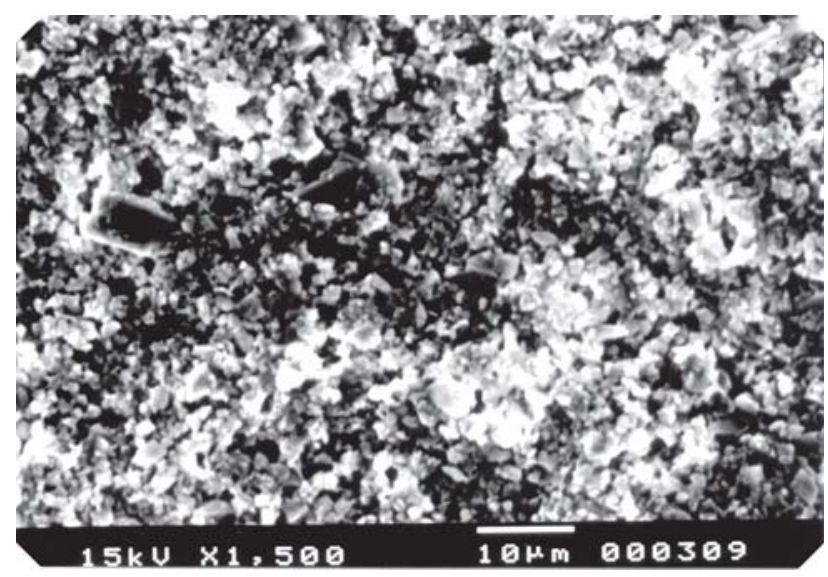

FIGURE 2- Abrasive particles of Dentu-Creme dentifrice organic deposits from dentures ${ }^{6,7}$. Murray, et al. ${ }^{14}$ (1986) found that there was no difference between Colgate and Dentu-Creme on plaque removal, even with their abrasiveness difference. However, these authors also showed that low abrasion dentifrices did not remove stains from smoker's dentures. Therefore, the abrasiveness is an important consideration to select a dentifrice. It should be abrasive enough to maintain the denture clean ${ }^{8}$.

One of the purposes of this study was to compare dentifrices in the same experimental conditions. Each specimen was subjected to 35,600 brushing strokes, and the load applied on each brush head was $200 \mathrm{~g}$, which was estimated to be equivalent to two years of manual brushing ${ }^{19}$. Correlation between "in vitro" tests with clinical reality is difficult. Artificial brushing is vigorous and may be more abrasive than manual brushing ${ }^{11}$, but some works show similar results between laboratory and clinical experiments ${ }^{12}$.

This study compared denture teeth that are different as for esthetics and cost. Vipi Dent Plus and Trubyte Biotone teeth are composed by two layers, while Trilux and Ivostar are composed by three and SR-Vivodent PE by four layers. This modification on manufacturing process determines esthetics and cost differences, but there was no significant difference among them for abrasion resistance. This result was not expected, but it is in accordance with Khan, et al. ${ }^{10}$ (1985), who compared different brands of denture teeth, which did not present any difference regarding wear resistance. On the other hand, Satoh, et al. ${ }^{17}$ (1990) studied the hardness and wear resistance to brushing of different denture teeth and found that the harder the teeth, the more resistant to abrasion they were.

Just few works ${ }^{17}$ were found about the abrasion resistance of acrylic denture teeth by brushing. Once the teeth are important denture components and are submitted to biofilm accumulation, this study is very relevant. In addition, the brushing of acrylic denture teeth with dentifrices promote esthetic problems ${ }^{17}$. "In vitro" assay aids generally help to compare the relative efficacy of denture cleansers and help to develop an understanding of the mode of action of each denture cleanser ${ }^{15}$. Clinical studies are necessary to enhance the existing findings and to determine the implication of the wear produced by dentifrices on dentures. It would help dentists on indication of cleansers for denture users.

\section{CONCLUSIONS}

Based on the results and within the limitations of an "in vitro" study, it may be concluded that the acrylic resin artificial teeth tested presented the same abrasion resistance by brushing; non-specific dentifrice for denture hygiene (Colgate) produced the greatest weight loss of the teeth. 


\section{REFERENCES}

1- Camargo, IMC, Saiki, M, Vasconcellos, MBA, Ávila, DM. Abrasiveness evaluation of silica and calcium carbonate used in the production of dentifrices. J Cosmet Sci. 2001;52:163-7.

2- Coffey, JP; Goodkind, RJ; Delong, R; Douglas, WH. In vitro wear of natural and artificial teeth. J Prosthet Dent. 1985;54:273-80.

3- Dyer, D, Macdonald, E, Newcombe, RG, Scratcher, C, Ley, F, Addy, M. Abrasion and stain removal by different manual toothbrushes and brush actions: studies in vitro. J Clin Periodontol. 2001;28:1217 .

4- Facq, JM, Volpe, AR. In vivo actual abrasiveness of three dentifrices against acrylic surfaces of veneer crowns. J Am Dent Assoc. 1970;80:317-23.

5- Haselden, CA, Hobkirk, JA, Pearson, GJ, Davies, EHA. Comparison between the wear resistance of three types of denture resin to three different dentifrices. J Oral Rehabil. 1998;25;335-9.

6- Heath, JR, Wilson, HJ. The effect of dentifrices on restorative materials. J Oral Rehabil. 1974;1:47-54.

7- Heath, JR, Davenport, JC, Jones, PA. The abrasion of acrylic resin by cleaning pastes. J Oral Rehabil. 1983; 10:159-75.

8- Hembre, ME, Hembre, JH. Relative abrasiveness of dentifrices. Dent Hyg. 1977;51:253-5.

9- Hirano, S; May, KB; Wagner, WC; Hacker, CH. In vitro wear of resin denture teeth. J Prosthet Dent. 1998;79:152-5.

10- Khan, Z; Morris, JC; von Fraunhofer, JA. Wear of anatomic acrylic resin denture teeth. J Prosthet Dent. 1985;53:550-1.

11- Manly, RS, Wiren, J, Manly, PJ, Keene, RC. A method for measurement of abrasion of dentin by toothbrush and dentifrice. J Dent Res. 1965;44:533-40.

12- Muhler, ID, Stookey, GK, Hassel, TM. The development and evaluation of an improved denture cleaning and polishing paste. J Indiana State Dent Assoc. 1969;48:17-27.

13- Murray, ID, McCabe, JF, Storer, R. Abrasivity of denture cleaning pastes “in vitro" and “in situ”. Br Dent J. 1986;161:137-41.

14- Murray, ID, Mccabe, JF, Storer, R. The relationship between the abrasivity and cleaning power of the dentifrice-type denture cleaners. Br Dent J. 1986;161:205-12.

15- Nikawa, H; Hamada, T; Yamashiro, H; Kumagai, H. A review of in vitro and in vivo methods to evaluate the efficacy of denture cleansers. Int J Prosthodont. 1999;12:153-9.

16- Purnaveja, S, Fletcher, AM, Ritchie, GM, Amin, WM, Moradians, S, Dodd, AW. Compability of denture cleansers with some new selfcuring denture base materials. Biomaterials. 1982;3:251-2.

17- Satoh, Y; Ohtani, K; Maejima, K; Morikawa, M; Matsuzu, M; Nagai, E. et al. Wear of artificial denture teeth by use of toothbrushes. Part 1: Abrasive wear of anterior teeth. J Nihon Univ Sch Dent. 1990;32:247-58.

18- Sexson, JS, Phillips, RW. Studies on the effects of abrasives on acrylic resins. J Prosthet Dent. 1951;1:454-71.

19- Vieira, DF, Phillips, RW. Influence of certain variables on the abrasion of acrylic resin veneering materials. J Prosthet Dent. 1962;12:720-31.
20- Von Fraunhofer, J. A.; Razavi, R.; Khan, Z. Wear characteristics of high-strength denture teeth. J Prosthet Dent. 1988;59:173-5.

21- Whitman, DJ. Mckinney, JE; Hinman, RW; Hesby, RA; Pelleu, G.B. In vitro wear rates of three types of commercial denture tooth materials. J Prosthet Dent.1987;57:243-6.

22- International Organization for Standardization. Technical specification 14569-1. Dental Materials - Guidance on testing of wear resistance - Part 1: wear by tooth brushing. Switzerland, ISO, 1999. 